\title{
RÉGI TORONYÓRA ÚJ RENDELTETÉSE
}

\section{A NEW DESIGNATION OF AN OLD TOWER CLOCK}

\author{
Márton László ${ }^{1}$, Talpas János ${ }^{2}$ \\ ${ }^{I}$ Erdélyi Múzeum-Egyesület, Müszaki Tudományok Szakosztálya, Kolozsvár, 400009 \\ Cluj-Napoca, str. Napocanr.2-4, martonlb@yahoo.com \\ ${ }^{2}$ Babeş-Bolyai Tudományegyetem, Kolozsvár, 400006 Cluj-Napoca, str. Clinicilor \\ nr.5-7.talpasjanos@gmail.com
}

\begin{abstract}
The seeking out of new touristic attractions, targets and including these in the classical itineraries constitutes a permanent task for tourism professionals. The discovery of technical relics may be a new note of color of their professional ambition. The renewal, reconditioning and putting in function of the Magyargyerőmonostor tower clock was one of the main goals of the Technical history research group within the Transylvanian Museum Society. The complex activity that was done in this direction leads to valorous research activity in the field of multidisciplinary.
\end{abstract}

Keywords: tower clock, history of technics, Magyargyerömonostor, touristical attraction.

\section{Összefoglalás}

A turisztikai szakemberek állandó feladata új turisztikai vonzáskörök, célpontok felkutatása, ezek bevonása a hagyományos útvonalakba. A technikatörténeti relikviák új színfoltjai lehetnek ennek a törekvésnek. A magyargyerőmonostori toronyóra felújítása, javítása, üzemképessé tétele az EME Müszaki Tudományok Szakosztálya Technikatörténeti kutatócsoportjának ez irányú törekvéseit is igazolja, ami interdiszciplináris kutatásokban is megnyilvánul.

Kulcsszavak: toronyóra, technikatörténet, Magyargyerömonostor, turisztikai vonzerö

\section{Bevezető}

A turizmus egy igen összetett gazdasági és szabadidős tevékenység, amelynek szociális, politikai, kulturális ráhatásai vannak napjaink tevékenységére $[1,2]$. Fejlesztésének alapfeltétele a kereslet ismerete.

A természeti adottságok észszerü hasznosítása a turizmus egyik alapgondolata. A turizmus egy dinamikusan fejlődő nemzetgazdasági ágazat, amelynek fő feladata pihentető, szórakoztató kikapcsolódást nyújtani jellegzetes szolgáltatásokkal. A turizmusban dolgozó szakemberek feladata, hogy magas szintü szakmai tudásukkal szolgálják a turizmusban részt vevő, pihenni, kikapcsolódni, élményeket szerezni óhajtó személyeket, csoportokat, hogy egyre több, új turisztikai értéket is képviselő lehetőség feltárásával, értékesítésével bővítsék a már létező, hagyományos turisztikai térségeket.

Ehhez a feltáró, interdiszciplináris munkához kell együttmüködniük turisztikai szakemberekkel, néprajzos, régész, történész, müvészettörténész és nem utolsósorban müszaki képzettségű személyeknek. 
A Kolozs megyei Kalotaszeg, az Alszeg, Felszeg, Nádas-mente három tájegységével, hagyományos, sürün látogatott turisztikai régió. Jellegzetes építészete, népviselete, tánckultúrája egyedi színfoltja Erdély kultúrtörténetének. Kevésbé ismert e tájegység technikatörténeti múltja, amely csupán a közelmúltban vált a kutatások témájává. Az Erdélyi Múzeum-Egyesület Müszaki Tudományok Szakosztálya évente megrendezett ez irányú, terepen végzett kutatásai számos, addig ismeretlen értéket azonosított, mért fel és tett ismertté technikatörténeti kiadványokban. Ezen kutatások következtében ismerhette meg az érdeklődő jó néhány kalotaszegi település templomának építészettörténetét, harangjait, toronyóráit: olyan értékek váltak közérdeklődés tárgyává, amelyek elhagyatva lassú, de biztos pusztulásra vannak ítélve. Ilyenek pl. a mechanikus toronyórák, egykor a település igényességét, gazdasági lehetőségeit is iga- zoló, müszaki csúcsteljesítményei annak az időszaknak, amelyben fénykorukat élték.

\section{A toronyóra mint turisztikai látványosság}

Egy keresztény templomnak számos szakrális és nem szakrális kelléke van. A templomi harang pl. a templomi liturgiában felhasznált szakrális kellék, míg a toronyóra nem részesül ebben a minősítésben.

Ez lehet egyik oka annak, hogy müködésének fenntartására nem fordítottak kellő figyelmet. Így a több száz éves toronyórák minden újabb nap elteltével a hosszú, de biztos végük felé tartanak. Az 1. ábra egy toronyóra elhanyagolt állapotát mutatja be. A mechanikus toronyóra az első automata gép, amely kora múszaki csodájának számított. Még ma is, számítógépes világunkban, rácsodálkozunk egy-egy müködőképes toronyórára.

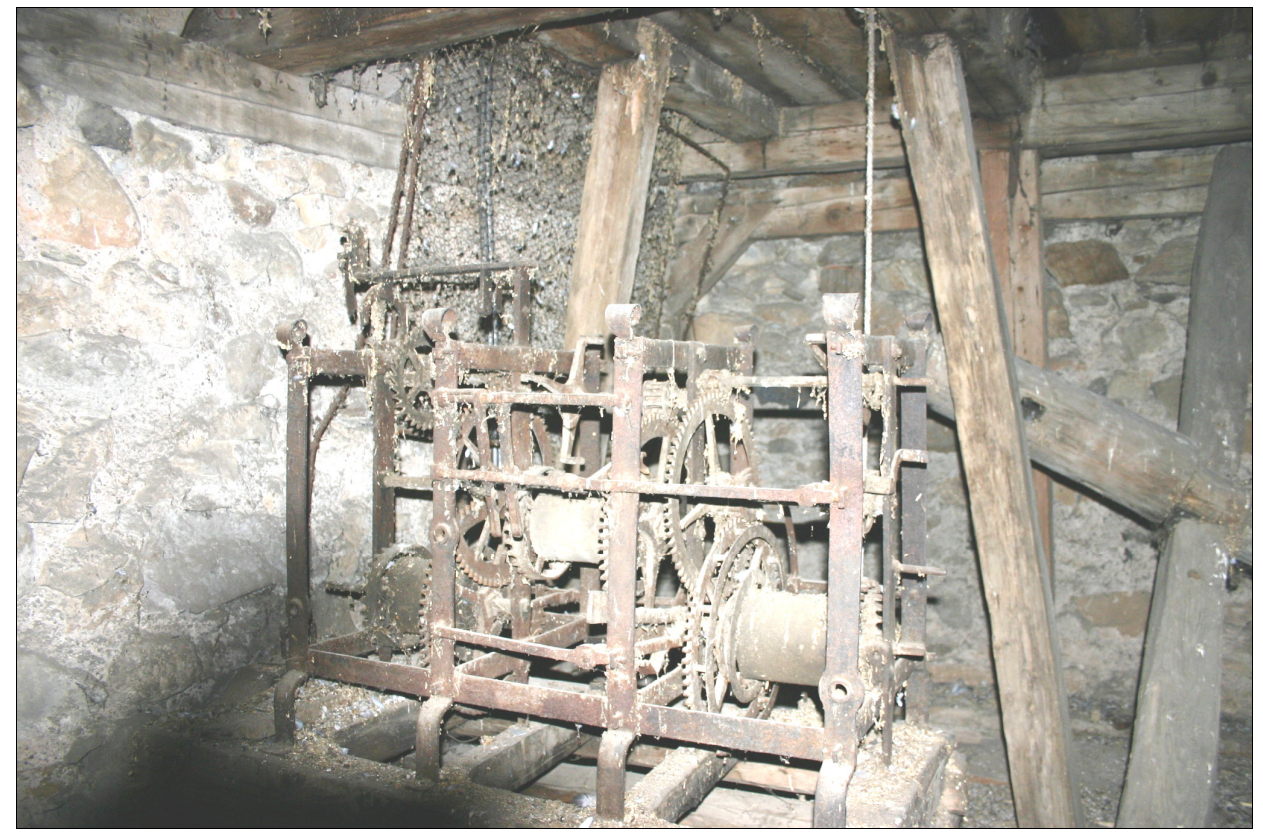

1. ábra. Elfelejtett, halálra itélt toronyóra (Gyergyótekeröpatak, 2016) 
A magyargyerőmonostori református templom, amely XV. században épült, egyike a késő gótika erdélyi képviselőinek, igazi gyöngyszeme a kalotaszegi templomépítészetnek [3,4]. Építészeti egyediségén kívül, a déli falán látható dombormüegyüttes és napóra megkülönböztető látványa jelentős élménnyel gazdagítja a nagyszámú látogatót, emiatt igazi turisztikai érdekességként vonult be a köztudatba.

Toronyórája (2. ábra), amely 1834-ben készült, egy nagyváradi toronyóra-készítő lakatos remekműve, 170 éves müködése után kegyvesztetté vált. Így állt működésképtelenül évtizedeken át, amíg 2008-ban az Erdélyi Múzeum-Egyesület Müszaki
Tudományok Szakosztályának technikatörténeti kutatócsoportja felmérte, azonosította és az egyház presbitériumának ajánlatot tett a toronyóra megjavítására, működőképessé tételére. A javaslatot a presbitérium elfogadta, és döntés született a toronyóra új elhelyezéséröl a torony alatti nyugati templomkapu bejáratot követő előcsarnokba. A javítási munkálatokat a gyergyószentmiklósi Mecatex Kft. szakembereire bízta. A toronyóra állványra helyezve, müködőképes állapotban, az elöre kialakított térben egy újabb turisztikai látványossága lett a templomnak, a településnek, egyedülállóként a maga nemében.

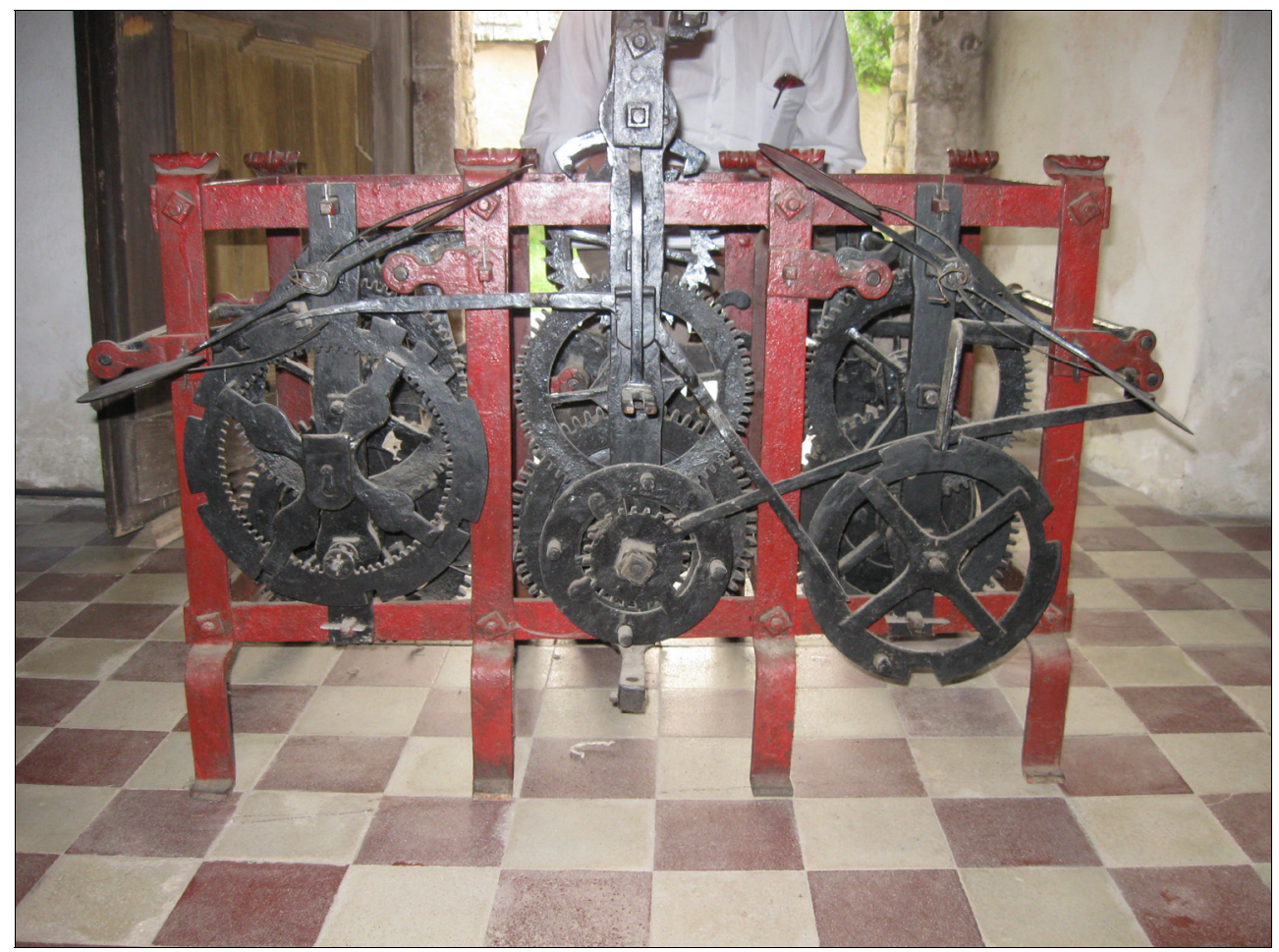

2. ábra. A leszerelt toronyóra 


\section{A felújítási-javítási munkálatok folyamata}

A javítási munkálatokat tüzetes vizsgálat elözte meg, amely a hiányzó és kicserélésre szoruló alkatrészek meghatározását eredményezte. Kopott síkcsapágyak, tengelyvégek, fogaskerekek fogainak hegesztése, majd névleges méretre hozása jelentette az alkatrészek javítását [5].

Hiányzott az inga, ennek tartószerkezetcsapágyazása, a kardáncsuklók az óra mutatóinak meghajtásához, a számlap, a mutatók, az ütőmodul kalapácsai és harangjai, valamint a szerkezet három modulját müködtető órasúlyok és kötelek.

Ezeket pótolva, a szerkezetet egy zárt szekrényből összeállított állványra helyezték. Az óra vázra való tételét a 3. ábra mutatja be.

A felújított, üzemképes toronyóra müködése [6] a 4. ábrán látható kinematikai rajzokon követhető.

Az állvány az inga szárainak hosszától függően, ennek lengési idejét figyelembe véve készült el (5. ábra). A számlap és a mutatók az eredeti számlap és mutatók kicsinyített másaiként készültek.

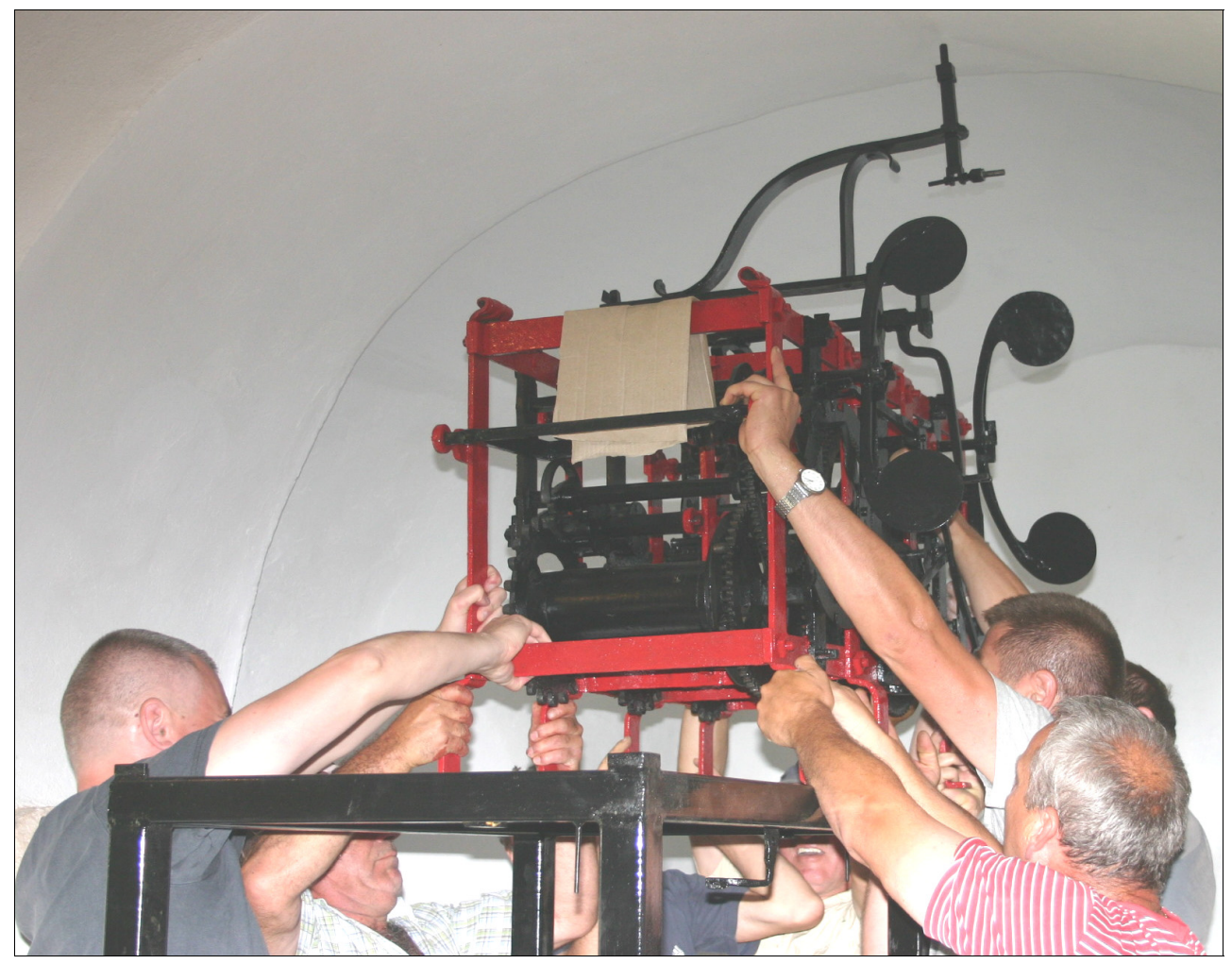

3. ábra. Az új állványra helyezés müvelete 

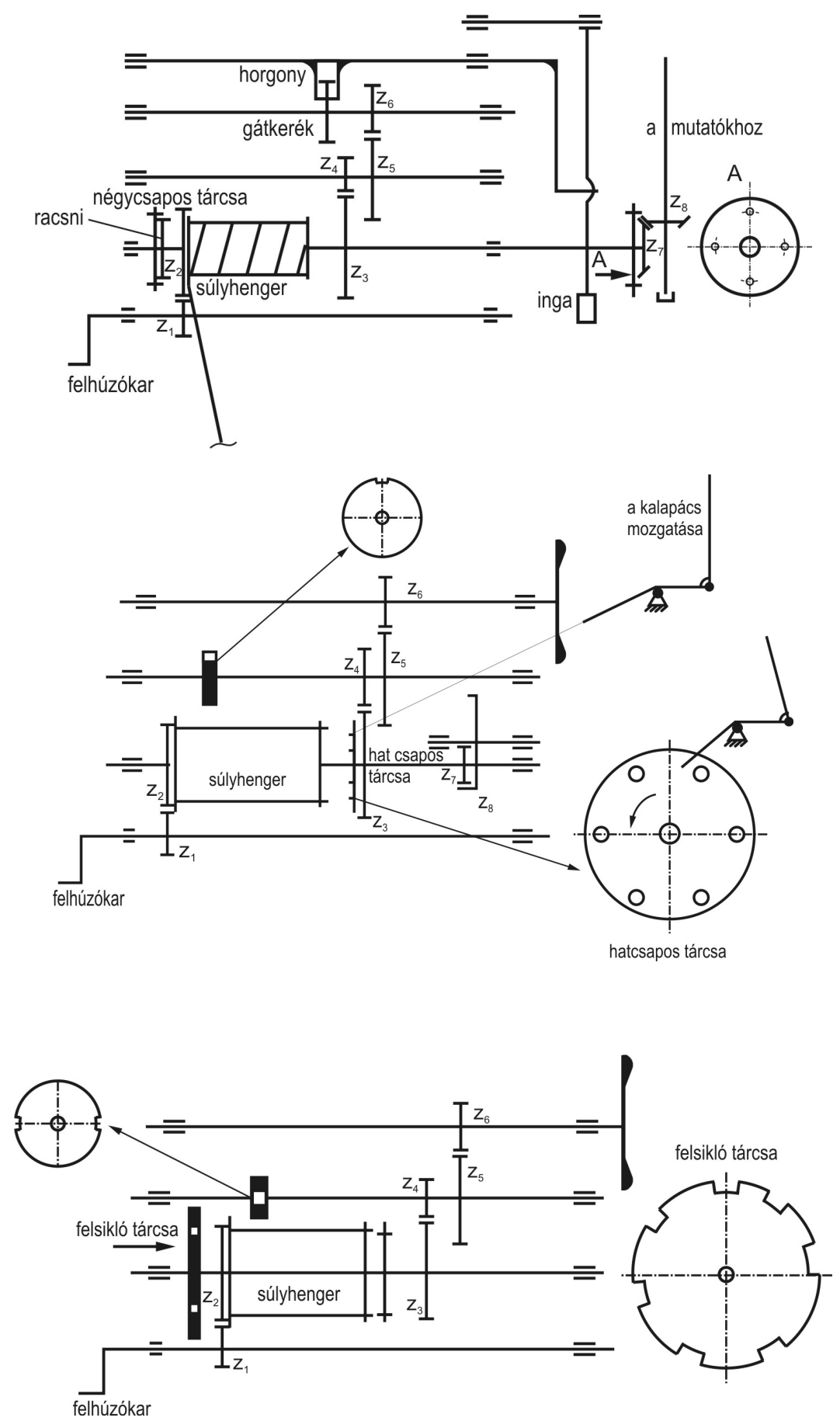

4. ábra. Az új turisztikai látványosság müködését bemutató kinematikai rajz [3] 


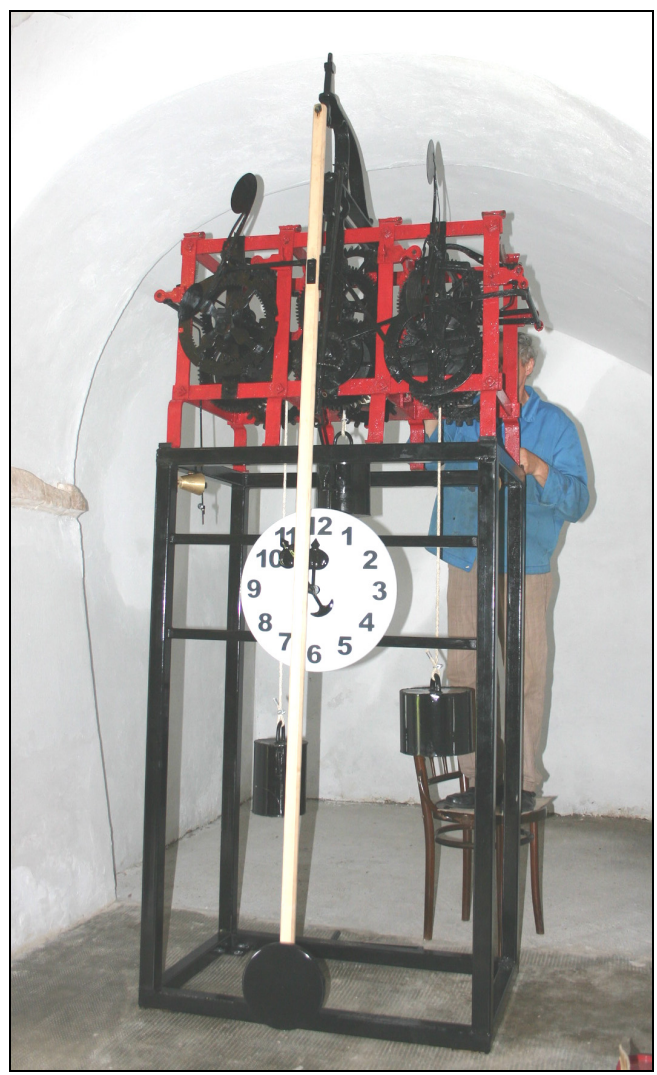

5. ábra. A felújitott, új életü toronyóra

\section{Következtetések}

A magyargyerőmonostori toronyóra felújítása iskolapéldaként kezelhető bármely másik toronyóra felújításánál. A több száz 2-300 éves mechanikus toronyóra felkutatása, felmérése, történetének kutatása, az eredmények közzé helyezése minden közösségnek mulaszthatatlan feladata. Minden felújított toronyóra új turisztikai célpont is lehet, ezáltal gazdagítva a hagyományos turisztikai látványosságok sorát.

\section{Szakirodalmi hivatkozások}

1. Hutiray Judit: Turisztikai alapismeretek. Képzőmüvészeti Kiadó, Budapest, 2000, 3. utánnyomás 2009.

2. Michalkó Gábor: Turizmológia. Elméleti alapok. Akadémiai Kiadó, Budapest, 2012.

3. Bitay Enikő, Márton László, Talpas János: Technikatörténeti örökség Magyargyerömonostoron. EME, Kolozsvár, 2010.

4. Márton László: Toronyórák, napórák Erdélyben. Pallas-Akadémia Könyvkiadó, Csíkszereda, 2005.

5. Magyar László: Óraipari zsebkönyv. Müszaki Könyvkiadó, Budapest, 1979. 